\title{
Development of a validated high-performance liquid chromatographic method for the determination of Lurasidone in pharmaceuticals
}

\author{
Sakine ATILA KARACA, Duygu YENICELİ UĞUR
}

\begin{abstract}
A new, rapid and simple HPLC method for determination of Lurasidone in its tablets has been developed and validated. Lurasidone and internal standard (Chlorpromazine) was separated on a Zorbax XDB C8 column (4.6 x $50 \mathrm{~mm}, 3.5$ $\mu \mathrm{m}$ particle size) set at $40^{\circ} \mathrm{C}$ and quantified by ultraviolet detection at $230 \mathrm{~nm}$. The mobile phase was phosphate buffer (pH:3, $20 \mathrm{mM})$ : acetonitrile: methanol (55:10:35, v/v/v) with a flow rate of $1.2 \mathrm{~mL} / \mathrm{min}$. Retention times of Chlorpromazine and Lurasidone was 4.73 and 6.89 minutes, respectively. The method was found linear over the concentration range of 0.5-50
\end{abstract}

$\mu \mathrm{g} / \mathrm{mL}$ Lurasidone. Limit of detection and quantification values for Lurasidone was 0.1295 and $0.4317 \mu \mathrm{g} / \mathrm{mL}$, respectively. The intra- and inter day precisions were less than $2 \%$ and the mean recoveries were $100.32 \%$, which indicated that the method was precise and accurate. All other validation parameters were found within acceptable limits. The validated method has been successfully applied for determination of Lurasidone in its tablets.

Keywords: Lurasidone; high performance liquid chromatography; tablet analysis; validation.
Sakine Atila Karaca, Duygu Yeniceli Uğur

Department of Analytical Chemistry, Faculty of Pharmacy, Anadolu University, 26470 Eskisehir, Turkey.

Corresponding Author:

Duygu Yeniceli Uğur

e-mail:dyeniceli@anadolu.edu.tr

Submitted / Gönderilme: 07.07.2017Ｒevised / Düzeltme: 01.08.2017 Accepted / Kabul: $\quad 02.08 .2017$

How to cite this article : Atila Karaca S, Yeniceli Uğur D. Development of a validated high-performance liquid chromatographic method for the determination of Lurasidone in pharmaceuticals. Marmara Pharm J. 2017; $21(4): 931-937$

\section{Introduction}

Lurasidone (LUR) is a benzothiazol derivative (Figure 1a) belonging to second-generation antipsychotics class. It is used for the treatment of schizophrenia and bipolar depression. Although its mechanism of action is not fully understood, it is believed that the efficacy of LUR is mediated mainly through antagonist activity at the dopamine D2, and the 5-hydroxytryptamine (5-HT, serotonin) receptors: 5-HT2A and 5-HT7 [1]. LUR demonstrated both antipsychotic and antidepressant action. Despite its side effects like higher rates of akathisia, parkinsonism and hyperprolactinemia, it has relatively lower risk for developing sedation or overweight/ obesity [1]. LUR is available as tablets under the brand name of Latuda.

Several chromatographic methods have been described for the quantification of LUR including spectrometry [2-5], TLC [6], HPTLC [7, 8], GC/MS [9], HPLC [8, 10-15] and LC/MS [16-21]. The goal of this study was the development of a new HPLC method for determination of LUR in its tablets. Although there are some previous HPLC methods 
developed for this purpose (Table 1), they allow analysis at a narrow concentration range. Also internal standard was not used in any of these methods except one HPLC method [10]. Developed method has a wide concentration range, low quantification limit and a comparable retention time. Besides advantageously from other methods an internal standard was employed to improve the precision of the analysis. It was validated according to the International Conference on Harmonization guideline [22] and applied for the analysis of tablets.

\section{Results}

\subsection{Method optimization}

Chromatographic conditions were optimized using different analytical columns, mobile phase compositions, mobile phase flow rates, injection volumes and column temperatures. During optimization studies, a solution containing $50 \mu \mathrm{g} /$ $\mathrm{mL}$ LUR was used. At the beginning of work, Zorbax Eclipse XDB-C8 column ( $4.6 \times 50 \mathrm{~mm}, 3.5 \mu \mathrm{m}$ particle size $)$ and Zorbax Eclipse Plus C18 column $(4.6$ x 100 mm, $3.5 \mu \mathrm{m}$ particle size) were tried as stationary phase. First column was chosen because it provided shorter analysis time with better peak morphology. Next, different mobile phase compositions containing water, acetonitrile and methanol were tested. However, due to high resolution times and poor peak symmetry, it was decided to use buffer solutions in mobile phase. Mobile phases containing phosphate buffer ( $\mathrm{pH} 3$ ) and acetate buffer ( $\mathrm{pH} 4$ and 5) were tried. As expected LUR, which is a weakly basic compound, eluted faster when mobile phase is more acidic. So phosphate buffer $(\mathrm{pH} 3)$ was selected and after testing different concentrations (10,20 and $30 \mathrm{mM}$ ), $20 \mathrm{mM}$ was selected as optimum buffer concentration. After all this steps, mobile phase composition was determined as phosphate buffer ( $\mathrm{pH}: 3,20 \mathrm{mM})$ : acetonitrile: methanol (55:10:35, v/v/v). Different flow rates between $0.7-1.2 \mathrm{~mL} /$ min were tested and shorter retention times with appropriate peak shapes were observed at a flow rate of $1.2 \mathrm{~mL} / \mathrm{min}$. Injection volume was set at $2 \mu \mathrm{L}$ considering the volume of the column. The influence of column temperature was investigated at 30,35 , and $40^{\circ} \mathrm{C}$ and it was set at $40^{\circ} \mathrm{C}$ due to reduced retention time with increasing temperature. $230 \mathrm{~nm}$, the wavelength at which maximum absorbance is observed, was determined by a spectrum taken with diode array detector. Chlorpromazine (CLP), Carbamazepine and Quetiapine were analyzed at optimized conditions to decide internal standard. CLP (Figure 1b) was selected because its retention time (4.73 minutes) was close to LUR with a good resolution (4.95) and its retention and tailing factors (10.23 and 1.08 , respectively) were appropriate. A chromatogram of LUR and CLP obtained at optimum chromatographic conditions is provided in Figure 2. The system suitability parameters are summarized in Table 2.

Table 1. Comparison of the HPLC methods developed for the determination of LUR in tablets.

\begin{tabular}{cccc}
\hline Reference & $\begin{array}{c}\text { Retention time of Lurasidone } \\
(\mathrm{min})\end{array}$ & $\begin{array}{c}\text { Linearity for Lurasidone } \\
(\mu \mathrm{g} / \mathrm{mL})\end{array}$ & $\begin{array}{c}\text { Quantification limit of Lurasidone } \\
(\mu \mathrm{g} / \mathrm{mL})\end{array}$ \\
\hline$[8]$ & 7.39 & $0.1-4.5$ & 0.005 \\
\hline$[10]$ & 5.30 & $5-25$ & 1.82 \\
\hline$[11]$ & 5.60 & $30-225$ & 0.23 \\
\hline$[12]$ & 4.33 & $10-50$ & 0.1980 \\
\hline$[13]$ & 3.33 & $10-60$ & 0.75 \\
\hline$[14]$ & 5.43 & $2.5-15.0$ & 0.2999 \\
\hline$[15]$ & 3.91 & $4-32$ & 2.193 \\
\hline Present method & 6.89 & $0.5-50$ & 0.4317 \\
\hline
\end{tabular}




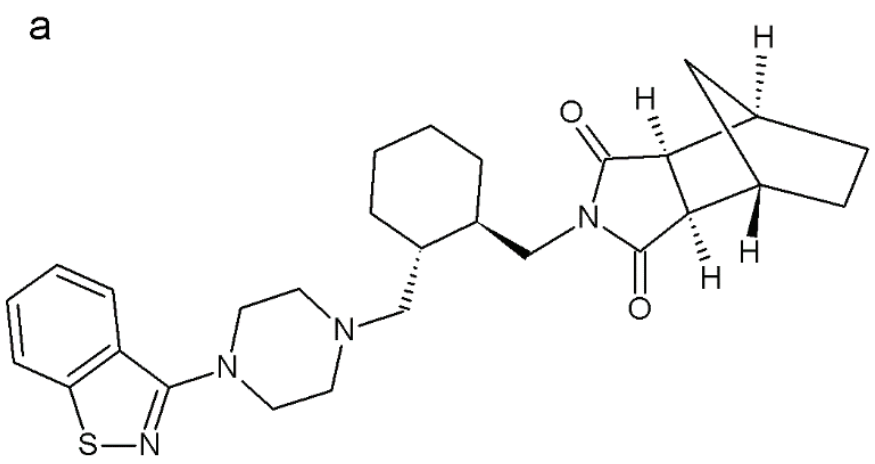<smiles>CN(C)CCCN1c2ccccc2Sc2ccc(Cl)cc21</smiles>

Figure 1. Chemical structures of LUR (a) and CLP (IS) (b).

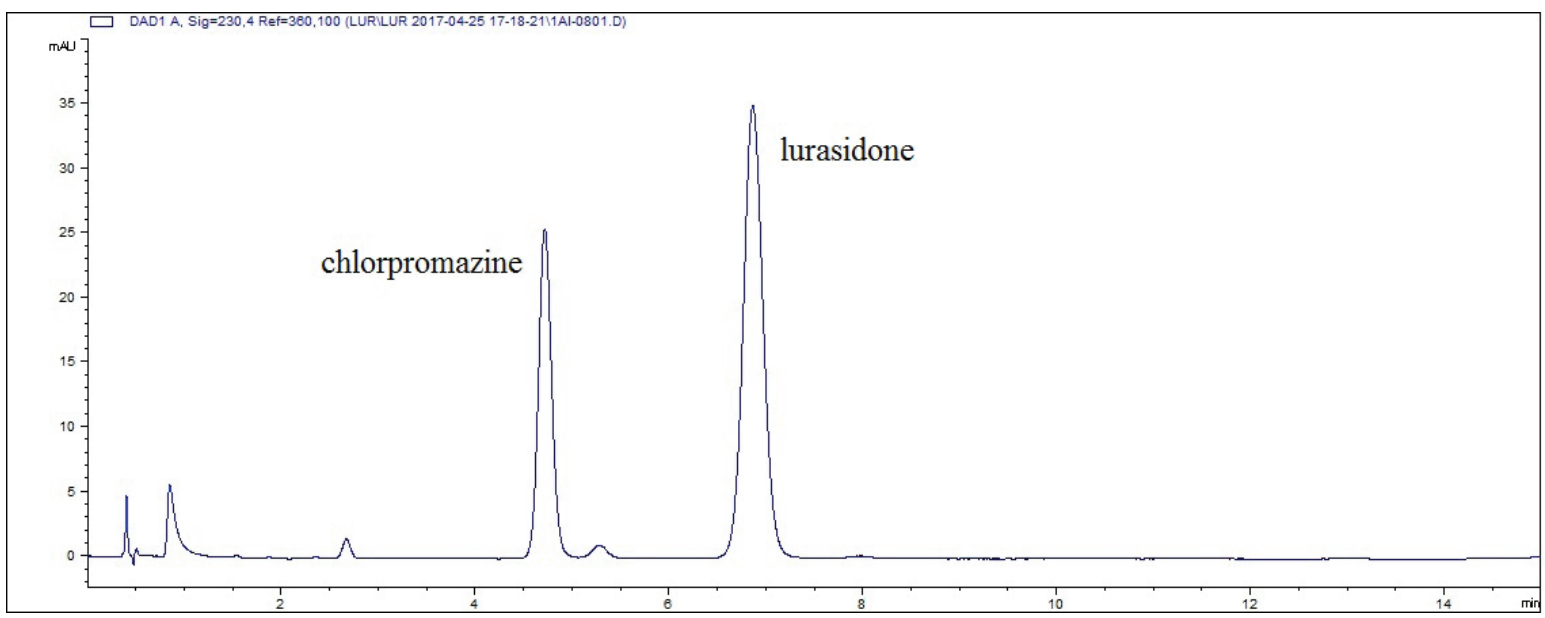

Figure 2. Chromatogram of LUR $(25.00 \mu \mathrm{g} / \mathrm{mL})$ and CLP (IS) $(10.00 \mu \mathrm{g} / \mathrm{mL})$ at optimum conditions.

\subsection{Method validation}

Validation studies were carried out according to the International Conference on Harmonization guideline Q2(R1) [22]. The method was validated for linear range, accuracy, precision, detection and quantification limits, specificity and robustness.

Linearity of the method was investigated in the range of $0.5-50 \mu \mathrm{g} / \mathrm{mL}$ LUR. Three calibration sets consisting of seven points in this concentration range were prepared and analyzed three times on three consecutive days. Linearity was evaluated by linear regression analysis using the least squares regression method and the results are summarized in Table 3.

Precision and accuracy studies were carried out by analyzing quality control solutions at three concentration levels of 1, 4 and $50 \mu \mathrm{g} / \mathrm{mL}$ LUR. Analyzes were performed seven times on three consecutive days. Precision of the method was expressed as relative standard deviation (RSD\%) and accuracy was expressed as percentage recovery values. As seen in Table 4 intra- and inter day RSD\% values were lower than $1 \%$, recovery values were between $98-102 \%$.

The accuracy of the method was also evaluated by analyzing the extracts of tablets spiked with 1,4 and $50 \mu \mathrm{g} / \mathrm{mL}$ LUR. As seen in Table 5, RSD\% values were found lower than 2\% and recovery values were between $98-102 \%$.

The detection and quantification limits of the method were calculated based on the signal-to-noise ratio and were found 0.1295 and $0.4317 \mu \mathrm{g} / \mathrm{mL}$, respectively.

Specificity of the method was evaluated by peak purity factor which was obtained from Agilent Chemstation. The purity factors of standard solution and tablet extraction solution (999.996 and 999.964, respectively) were found within the calculated threshold limit.

No interference caused by tablet excipients was observed in the chromatograms during tablet analysis, indicating the specificity of the method. 
Table 2. System suitability parameters $(\mathrm{n}=7,4.00 \mu \mathrm{g} / \mathrm{mL})$.

\begin{tabular}{lcc}
\hline Parameter & Observed value & Requested value \\
\hline Retention time (min) & 6.977 & - \\
\hline Retention factor (k) & 15.56 & $2-10$ \\
\hline Tailing factor (T) & 1.04 & $\leq 2$ \\
\hline Resolution (Rs) & 6.35 & $>2$ \\
\hline Theoretical number of plates (N) & 4752 & $>2000$ \\
\hline Relative standard deviation (\%) of retention time & 0.03 & $<1$ \\
\hline
\end{tabular}

Table 3. Linearity data for $0.5-50 \mu \mathrm{g} / \mathrm{mL}$ LUR.

\begin{tabular}{|c|c|c|}
\hline & $\begin{array}{l}\text { Intra-day } \\
\text { (Day I, n=7) }\end{array}$ & $\begin{array}{c}\text { Inter-day } \\
\text { (Whole days, } \mathrm{n}=21 \text { ) }\end{array}$ \\
\hline Slope, mean \pm standard deviation & $0.0845 \pm 0.0004$ & $0.0852 \pm 0.0003$ \\
\hline Intercept, mean \pm standard deviation & $-0.0234 \pm 0.0077$ & $-0.0284 \pm 0.0067$ \\
\hline Coefficient of determination $\left(\mathrm{r}^{2}\right)$ & 0.9999 & 0.9997 \\
\hline $95 \%$ confidence limits of slope & $0.0836-0.0854$ & $0.0846-0.0859$ \\
\hline
\end{tabular}

Table 4. Precision and accuracy for 1.00, 4.00, and 50.00 $\mu \mathrm{g} / \mathrm{mL}$ LUR.

\begin{tabular}{|c|c|c|c|c|c|}
\hline & \multirow{2}{*}{$\begin{array}{c}\text { Added } \\
\text { Concentration } \\
(\mu \mathrm{g} / \mathrm{mL})\end{array}$} & \multirow{2}{*}{$\begin{array}{c}\text { Measured } \\
\text { concentration } \\
(\mu \mathrm{g} / \mathrm{mL})\end{array}$} & \multicolumn{2}{|c|}{ Precision } & \multirow{2}{*}{$\begin{array}{c}\text { Accuracy } \\
\text { Recovery } \\
(\%)\end{array}$} \\
\hline & & & $\begin{array}{l}\text { Standard } \\
\text { deviation }\end{array}$ & $\begin{array}{c}\text { Relative } \\
\text { standard } \\
\text { deviation }(\%)\end{array}$ & \\
\hline \multirow{3}{*}{$\begin{array}{l}\text { Intra-day } \\
\text { (Day I, } n=7 \text { ) }\end{array}$} & 1.00 & 0.9965 & 0.0033 & 0.3329 & 99.65 \\
\hline & 4.00 & 3.9313 & 0.0063 & 0.1591 & 98.28 \\
\hline & 50.00 & 50.6662 & 0.0796 & 0.1571 & 101.33 \\
\hline \multirow{3}{*}{$\begin{array}{l}\text { Inter-day } \\
\text { (Whole days, } n=21 \text { ) }\end{array}$} & 1.00 & 1.0083 & 0.0101 & 0.9995 & 100.83 \\
\hline & 4.00 & 3.9443 & 0.0353 & 0.8938 & 98.61 \\
\hline & 50.00 & 50.7635 & 0.1286 & 0.2534 & 101.53 \\
\hline
\end{tabular}

The robustness of the method was investigated by introducing small deliberate changes in chromatographic conditions. For this purpose, minor changes were made in organic mobile phase composition, $\mathrm{pH}$ and buffer concentration, flow rate, column temperature, and detector wavelength and analysis of $4 \mu \mathrm{g} / \mathrm{mL}$ LUR were performed three replicated in the altered conditions. Modified conditions, recoveries and system suitability parameters observed in these conditions were given in Table 6 . As seen in the table, all recovery values were between $98-102 \%$. 


\subsection{Application of the method to tablets}

The developed method was applied successfully for the quantification of LUR in its tablets. Tablet solutions containing 1,4 , and $50 \mu \mathrm{g} / \mathrm{mL}$ LUR were analyzed seven times. Labeled and found tablet contents and recovery values were given in Table 7 . Recovery values close to $100 \%$ and chromatograms without interferences demonstrated the applicability of the method for the tablet analysis.

Table 5. Accuracy in tablet extracts for $1.00,4.00$, and $50.00 \mu \mathrm{g} / \mathrm{mL}$ LUR $(\mathrm{n}=7)$.

\begin{tabular}{|c|c|c|c|c|}
\hline $\begin{array}{c}\text { Added } \\
\text { Concentration } \\
(\mu \mathrm{g} / \mathrm{mL})\end{array}$ & $\begin{array}{c}\text { Measured } \\
\text { Concentration } \\
(\mu \mathrm{g} / \mathrm{mL})\end{array}$ & $\begin{array}{l}\text { Standard } \\
\text { deviation }\end{array}$ & $\begin{array}{l}\text { Relative standard deviation } \\
(\%)\end{array}$ & $\begin{array}{c}\text { Recovery } \\
(\%)\end{array}$ \\
\hline 1.00 & 1.0112 & 0.0187 & 1.8509 & 101.12 \\
\hline 4.00 & 4.0114 & 0.0230 & 0.5740 & 100.29 \\
\hline 50.00 & 50.9438 & 0.2662 & 0.5225 & 101.89 \\
\hline
\end{tabular}

Table 6. Robustness for $4.00 \mu \mathrm{g} / \mathrm{mL}$ LUR $(\mathrm{n}=3)$.

\begin{tabular}{|c|c|c|c|c|c|}
\hline Parameter & & Recovery (\%) & Retention time (min) & $\begin{array}{l}\text { Number of theoretical } \\
\text { plates }\end{array}$ & Tailing factor \\
\hline \multirow{2}{*}{$\begin{array}{l}\text { Flow rate } \\
(\mathrm{mL} / \mathrm{min})\end{array}$} & 1.1 & $98.85 \pm 0.40$ & $7.618 \pm 0.013$ & $4838 \pm 23$ & $1.01 \pm 0.00$ \\
\hline & 1.3 & $100.29 \pm 0.17$ & $6.424 \pm 0.011$ & $4630 \pm 24$ & $1.00 \pm 0.01$ \\
\hline \multirow{2}{*}{$\begin{array}{l}\text { Column temperature } \\
\left({ }^{\circ} \mathrm{C}\right)\end{array}$} & 38 & $100.47 \pm 0.25$ & $7.271 \pm 0.006$ & $4750 \pm 7$ & $1.04 \pm 0.02$ \\
\hline & 42 & $101.35 \pm 0.06$ & $6.612 \pm 0.016$ & $4580 \pm 86$ & $1.03 \pm 0.01$ \\
\hline \multirow{2}{*}{$\begin{array}{l}\text { Detector wavelength } \\
(\mathrm{nm})\end{array}$} & 228 & $101.36 \pm 0.50$ & $7.013 \pm 0.012$ & $4775 \pm 22$ & $1.00 \pm 0.01$ \\
\hline & 232 & $98.57 \pm 0.15$ & $6.858 \pm 0.004$ & $4366 \pm 34$ & $1.03 \pm 0.01$ \\
\hline \multirow{2}{*}{$\begin{array}{l}\text { The percentage of acetonitrile } \\
(\%)\end{array}$} & 8 & $99.63 \pm 0.02$ & $9.085 \pm 0.008$ & $3827 \pm 96$ & $1.05 \pm 0.00$ \\
\hline & 12 & $101.72 \pm 0.06$ & $4.654 \pm 0.005$ & $3657 \pm 99$ & $1.04 \pm 0.00$ \\
\hline \multirow{2}{*}{$\begin{array}{l}\text { The percentage of methanol } \\
(\%)\end{array}$} & 33 & $99.77 \pm 0.13$ & $8.280 \pm 0.008$ & $3856 \pm 44$ & $1.04 \pm 0.01$ \\
\hline & 37 & $101.44 \pm 0.06$ & $5.138 \pm 0.009$ & $3883 \pm 55$ & $1.02 \pm 0.01$ \\
\hline \multirow{2}{*}{ Buffer concentration (mM) } & 18 & $100.55 \pm 0.30$ & $7.852 \pm 0.007$ & $4140 \pm 34$ & $1.04 \pm 0.01$ \\
\hline & 22 & $100.46 \pm 0.04$ & $7.093 \pm 0.002$ & $4040 \pm 75$ & $1.03 \pm 0.00$ \\
\hline \multirow{2}{*}{$\mathrm{pH}$} & 2.9 & $98.65 \pm 1.27$ & $6.730 \pm 0.045$ & $3962 \pm 52$ & $1.03 \pm 0.01$ \\
\hline & 3.1 & $100.43 \pm 0.08$ & $7.396 \pm 0.004$ & $4838 \pm 23$ & $1.04 \pm 0.00$ \\
\hline
\end{tabular}

Table 7. Assay results of LUR in tablets.

\begin{tabular}{ccccc}
\hline Formulation & $\begin{array}{c}\text { Labeled amount }(\mathrm{mg} / \\
\text { tablet })\end{array}$ & $\begin{array}{c}\text { Founded amount } \\
(\mathrm{mg} / \text { tablet })\end{array}$ & $\begin{array}{c}\text { Recovery } \\
(\%)\end{array}$ & $\begin{array}{c}\text { Relative } \\
\text { standard } \\
\text { deviation } \\
(\%)\end{array}$ \\
$\begin{array}{c}\text { Tablets (brand name } \\
\text { Latuda) }\end{array}$ & 37 & $37.13 \pm 0.43$ & 100.36 & 1.17 \\
\hline
\end{tabular}




\section{Conclusion}

HPLC is a common analytical technique used for the routine analysis of pharmaceutical products. In this study a new, rapid and simple liquid chromatographic method for determination of LUR has been developed. Developed method was validated and successfully applied for tablet analysis. Suggested method can be reliably used in routine analysis of pharmaceutical products.

\section{Materials and Methods}

\subsection{Materials}

LUR and CLP were purchased from MedChemExpress (USA) and Sigma Aldrich (Germany), respectively. All solvents were HPLC grade from Sigma Aldrich (Germany). Potassium dihydrogen phosphate and phosphoric acid were from Merck (Germany). Latuda tablets (each containing 37 mg LUR) were purchased from Takeda Pharma (Germany).

\subsection{Preparation of standard solutions}

Stock solutions of LUR and CLP at $1 \mathrm{mg} / \mathrm{mL}$ were prepared in methanol using LUR hydrochloride and CLP hydrochloride, respectively. Stock solutions were stored at $-20^{\circ} \mathrm{C}$ and further dilutions to obtain calibration and quality control solutions were made in methanol. Calibration solutions were prepared by serial dilution containing $0.5,1,2,4,10,25,50 \mu \mathrm{g} / \mathrm{mL}$ LUR. Quality control solutions were prepared at three concentrations of $1,4,50 \mu \mathrm{g} / \mathrm{mL}$. All calibration and quality control solutions were included $10 \mu \mathrm{g} / \mathrm{mL}$ CLP.

\subsection{Sample preparation}

Stock solutions of LUR tablets at $1 \mathrm{mg} / \mathrm{mL}$ were prepared in methanol. For this purpose, Latuda tablets (each containing $37 \mathrm{mg}$ LUR) were weighted and powdered in a mortar. Appropriate amount powder was dissolved in methanol. This mixture was sonicated for 30 minutes and centrifuged at $4000 \mathrm{rpm}$ for 10 minutes. Supernatant was separated and used to prepare sample solutions containing 1,4 and $50 \mu \mathrm{g} /$ $\mathrm{mL}$ LUR and $10 \mu \mathrm{g} / \mathrm{mL}$ CLP.

\subsection{Instrumentation and chromatographic conditions}

The HPLC system was an Agilent 1290 Infinity LC system (Agilent, Germany) consisting of a binary pump, a degasser, an autosampler, a thermostated column compartment, and a diode array detector. Separation was performed on a Zorbax XDB C8 column ( $4.6 \times 50 \mathrm{~mm}, 3.5 \mu \mathrm{m}$ particle size $)$ set at $40^{\circ} \mathrm{C}$. The mobile phase was phosphate buffer ( $\mathrm{pH}: 3,20$ $\mathrm{mM})$ : acetonitrile: methanol $(55: 10: 35, \mathrm{v} / \mathrm{v} / \mathrm{v})$ with a flow rate of $1.2 \mathrm{~mL} / \mathrm{min}$ and injection volume of $2 \mu \mathrm{L}$. The compounds were quantified by ultraviolet detection at $230 \mathrm{~nm}$.

\subsection{Software}

Microsoft Excel and GraphPad Prism 6 were employed for calculations. The peak area ratio [peak area of LUR /peak area of internal standard (CLP)] was used for calculations.

\section{Acknowledgements}

The authors thank Research Council of Anadolu University for the support of the Project (Project No: 1302S023).

\section{Authorship statement}

Author contributions: Concept - D.Y.U., S.A.K.; Design D.Y.U., S.A.K.; Supervision - D.Y.U.; Resource - D.Y.U.; Materials - D.Y.U.; Data Collection and/or Processing S.A.K.; Analysis and/or Interpretation - S.A.K.; Literature Search - D.Y.U., S.A.K.; Writing - S.A.K.; Critical Reviews - D.Y.U., S.A.K.

\section{Conflict of interest statement}

The authors declared no conflict of interest.

\section{References}

1. Jaeschke RR, Sowa-Kućma M, Pańczyszyn-Trzewik P, Misztak P, Styczeń, K, Datka, W. Lurasidone: The 2016 update on the pharmacology, efficacy and safety profile. Pharmacol Rep 2016; 68: 748-55.

2. Nikita M, Jignesh P, Mandev P. Validated spectrophotometric methods for the estimation of Lurasidone hydrochloride in bulk and pharmaceutical dosage forms. Int J Res Pharm Sci 2012; 2: 44-50.

3. Ravisankar P, Rajyalakshmi G Devadasu Ch, Devala RG. Validated UV spectrophotometric method for quantitative analysis of Lurasidone hydrochloride in pharmaceutical dosage form. Der Pharmacia Sinica 2014; 5: 1-7.

4. Vijaya Sri K, Sravani S, Kumar MS. Development and validation of UV spectrophotometric method for estimation of Lurasidone in bulk and pharmaceutical formulations. Asian J Pharm Res 2015; 5: 102-7.

5. Sudhir MS, Nadh RV. Simple and validated ultraviolet spectrophotometric method for the estimation of Lurasidone in bulk form. Res J Pharm Biol Chem Sci 2013; 4: 609-17. 
6. Patel RB, Vekaria KB, Patel MR. TLC-densitometric method for quantitation of Lurasidone hydrochloride in nanoemulsion, microemulsion, for equilibrium solubility and ex vivo diffusion studies. TJPS 2016; 40: 32-41.

7. Polawar AR, Damle MC. Development and validation of stability indicating HPTLC method for quantification of Lurasidone HCl. Pharma Sci Monitor 2014; 5: 131-44.

8. Sangeetha RK. Method development and validation for the estimation of Lurasidone by RP-HPLC and HPTLC. Eur J Pharm Med Res 2015; 2: 529-40.

9. Logarinho F, Rosado T, Lourenco C, Barroso M, Araujo AR, Gallardo E. Determination of antipsychotic drugs in hospital and wastewater treatment plant samples by gas chromatography/tandem mass spectrometry. J Chromatogr B Analyt Technol Biomed Life Sci 2016; 1038: 127-35.

10. Polawar AR, Damle MC. Development and validation of RPHPLC method for estimation of Lurasidone hydrochloride in bulk and pharmaceutical dosage form. Int J Res Pharm Chem 2014; 4: 327-32.

11. Chhabda PJ, Balaji M, Srinivasarao V, Appa Rao KMCh. Development and validation of stability indicating method for determination of Lurasidone in bulk drug and pharmaceutical dosage form by HPLC. IJPRD 2013; 5: 103-14.

12. Ravisankar P, Rajyalakshmi G, Dasu ChD, Babu PS, Reddy PV. Novel analytical method development and validation for the quantitative analysis of Lurasidone hydrochloride in bulk and pharmaceutical dosage forms by RP-HPLC. World J Pharm Res 2014; 3: 453-66.

13. Suneetha A, Manasa K, Sindhura SL. Stability indicating RPHPLC method for determination and validation of Lurasidone $\mathrm{HCl}$ in bulk and pharmaceutical dosage forms. J Pharm Res 2015; 1: 15-9.

14. Rao BK, Ramu G, Rani P, Rambabu C. Assay of Lurasidone by a stability indicating RP-HPLC method. Am J PharmTech Res 2014; 4: 449-68.
15. Patel KY, Patel SA. Development and validation of reverse phase high performance liquid chromatography method for estimation of Lurasidone hydrochloride in synthetic mixture. Int J Pharm Drug Anal 2014; 2: 169-73.

16. Patteet L, Maudens KE, Sabbe B, Morrens M, De Doncker M, Neels $\mathrm{H}$. High throughput identification and quantification of 16 antipsychotics and 8 major metabolites in serum using ultra-high performance liquid chromatography-tandem mass spectrometry. Clin Chim Acta 2014; 429: 51-8.

17. Katteboina MY, Pilli NR, Mullangi R, Seelam RR, Satla SR. LC-MS/MS assay for the determination of Lurasidone and its active metabolite, ID-14283 in human plasma and its application to a clinical pharmacokinetic study. Biomed Chromatogr 2016; 30: 1065-74.

18. Koo TS, Kim SJ, Lee J, Ha DJ, Baek M, Moon H. Quantification of Lurasidone, an atypical antipsychotic drug, in rat plasma with high-performance liquid chromatography with tandem mass spectrometry. Biomed Chromatogr 2011; 25: 1389-94.

19. Chae YJ, Koo TS, Lee KR. A sensitive and selective LC-MS method for the determination of Lurasidone in rat plasma, bile, and urine. Chromatographia 2012; 75: 1117-28.

20. Talluri MV, Dharavath S, Kalariya PD, Prasanth B, Srinivas R. Structural characterization of alkaline and oxidative stressed degradation products of Lurasidone using LC/ESI/QTOF/ MS/MS. J Pharm Biomed Anal 2015; 105: 1-9.

21. Patteet L, Maudens KE, Stove CP, Lambert WE, Morrens M, Sabbe B, Neels H. The use of dried blood spots for quantification of 15 antipsychotics and 7 metabolites with ultra-high performance liquid chromatography - tandem mass spectrometry. Drug Test Anal 2015; 7: 502-11.

22. The International Council for Harmonisation of Technical Requirements for Pharmaceuticals for Human Use (ICH). Validation of analytical procedures: Text and methodology, Q2(R1). Harmonized Tripartite Guideline. 2005. 